\title{
ROLA BILJANY PLAVŠIĆ W PIERWSZYCH LATACH ISTNIENIA REPUBLIKI SERBSKIEJ W BOŚNI I HERCEGOWINIE (BIH) (1992-1998)
}

\author{
MONIKA SKRZESZEWSKA
}

\begin{abstract}
The role of Biljana Plavšić in the early years of the Republika Srpska (1992-1998). Biljana Plavšić was one of the leading politicians of the Republika Srpska in the 90s. During the war (19921995) she was called an Iron Lady because of her promotion of extreme nationalist views. This nickname previously belonged to the Prime Minister Margaret Thatcher because she was a strong politician. The question is whether Plavšić was an equally strong politician? After the war, she was the President of the Republika Srpska, but she was against her old political collaborators. In addition, as the only accused, Plavšić admitted her guilt during the Bosnian war in the International Criminal Tribunal of the former Yugoslavia. Her role, however, is usually neglected in the literature about war in Bosnia and Herzegovina, that is why, this article would like to discuss the Plavšić's role.
\end{abstract}

Autor: Monika Skrzeszewska, Uniwersytet Jagielloński, Wydział Filologiczny, Instytut Filologii Słowiańskiej, ul. Władysława Reymonta 4, 30-059 Kraków, skrzeszewska@gmail.com

Słowa kluczowe: Bośnia i Hercegowina, Biljana Plavšić, wojna bośniacka, Radovan Karadžić

Keywords: Bosnia and Herzegovina, Biljana Plavšić, Bosnian war, Radovan Karadžić

Balcanica Posnaniensia. Acta et studia, XXIII, Poznań 2016, Wydawnictwo Instytutu Historii UAM, pp. 109134, ISBN 978-83-65663-26-9, ISSN 0239-4278. Polish text with a summary in English.

doi.org/10.14746/bp.2016.23.8

Biljana Plavšić była jedną z czołowych postaci w procesie kształtowania się instytucji politycznych, reprezentujących interesy bośniackich Serbów w okresie rozpadu federacji jugosłowiańskiej. Zaliczano ją wówczas do establishmentu politycznego Republiki Serbskiej (RS) - separatystycznego parapaństwa, funkcjonującego w warunkach konfliktu bośniackiego (1992-1995). Po wojnie, w latach 1996-1998 była ona prezydentem Republiki Serbskiej -tworu politycznego o statusie autonomicznym, który na mocy traktatu pokojowego z Dayton (1995) znajduje się w granicach państwowych Bośni i Hercegowiny (BiH). Obecnie B. Plavšić jest na marginesie życia politycznego i tylko sporadycznie występuje publicznie.

$\mathrm{W}$ odniesieniu do pierwszego etapu jej biografii politycznej, w literaturze przedmiotu i na łamach prasy stosowane jest określenie „Żelazna Dama”. Epitet ten przypisano wcześniej brytyjskiej premier Margaret Thatcher, która w stanowczy sposób krytykowała Związek Socjalistycznych Republik Radzieckich, a przy prowadzeniu 
polityki wewnętrznej wielokrotnie wykazywała nieprzejednaną postawę ${ }^{1}$. Zasadność użycia wspomnianego przydomka wobec B. Plavšić budzi wątpliwości ze względu na jego niejednoznaczność. Część obserwatorów, m.in. Carol S. Lilly i Jill A. Irvine, uważa, że miano Iron Lady odnosi się do jej wypowiedzi publicznych o zabarwieniu nacjonalistycznym, częstokroć rasistowskim, w których wykazywała szowinistyczny stosunek do nieserbskich wspólnot etnicznych (zwłaszcza muzułmańskiej) zamieszkujących $\mathrm{BiH}^{2}$. Istotnie, jak pisał Carl Bildt, mediator z ramienia Unii Europejskiej podczas konfliktu bośniackiego a następnie współprzewodniczący negocjacji pokojowych w Dayton i pierwszy Wysoki Przedstawiciel w BiH (do połowy $1997 \mathrm{roku}$ ), B. Plavšić początkowo kojarzyła mu się wyłącznie z ultranacjonalistycznymi poglądami, które prezentowała będąc we władzach samozwańczej $\mathrm{RS}^{3}$.

W przypadku ustalenia roli B. Plavšić w konflikcie bośniackim i po jego zakończeniu, badacz napotyka poważne trudności ze względu na kłopoty z ustaleniem jej rzeczywistego wpływu na procesy kształtowania instytucjonalnej reprezentacji Serbów w BiH w latach dziewięćdziesiątych XX wieku. I tak, zdaniem amerykańskiej badaczki Swanne Hunt, serbska polityk była powiązana z najwyższym aparatem władzy RS podczas wojny bośniackiej. Używa ona tutaj określenia „diabelskie trio", zaliczając do niego oprócz B. Plavšić, Radovana Karadžicia i Ratko Mladicia. Zdaniem S. Hunt, cała trójka odgrywała pierwszoplanową rolę w polityce Serbów bośniackich w ostatniej dekadzie XX wieku ${ }^{4}$. Z drugiej strony, inni badacze zajmujący się politycznym tłem konfliktu w BiH traktują Żelazną Damę raczej jako postać z kręgu lidera Serbów bośniackich, wspomnianego R. Karadžicia, bez zasadniczego wpływu na poczynania władz samozwańczego państwa. Trzeba zauważyć, że jednoznaczna ocena roli B. Plavšić w polityce serbskiej i bośniackiej jest utrudniona ze względu na luki bądź nieścisłości występujące w literaturze źródłowej o okolicznościach i następstwach rozpadu federacji jugosłowiańskiej.

Biljana Plavšić urodziła się 7 lipca 1930 roku w Tuzli, wówczas w Królestwie Jugosławii (1929-1941)5. Dzieciństwo i lata szkolne spędziła w Sarajewie. Po II wojnie światowej przeprowadziła się do Zagrzebia, gdzie studiowała biologię ${ }^{6}$, a w 1967

\footnotetext{
${ }^{1}$ M. Habarta, Kobiety zbrodniarki. Na przekór bałkańskiemu patriarchalizmowi i stereotypom ptci, „Znaczenia. Kultura-komunikacja-społeczeństwo”, 2014, nr 10 - http://www.e-znaczenia.pl/?p=1095, [dostęp: 24.09.2016].

${ }^{2}$ C.S. Lilly, J.A. Irvine, Leading the Nation: Extreme Right Women Leaders Among the Serbs, w: Women of the Right. Comparisions and Interplay Across Borders, red. K.M. Blee, S. McGee Deutsch, United States of America 2012, s. 268.

${ }^{3}$ C. Bildt, Peace Journey. The Struggle for Peace in Bosnia, Great Britain 1998, s. 176.

${ }^{4}$ S. Hunt, World Apart. Bosnian Lessons for Global Security, United States of America 2011, s. 137.

${ }^{5}$ B.A. Cook, Plavsic, Biljana (1930 -), w: Women and War. A Historical Encyclopedia from Antiquity to the Present, red. B.A. Cook, United States of America 2006, t. 2, s. 469.

${ }^{6}$ Biljana Plavšić, w: Republika Srpka. Prvi internet portal Republike Srpske - http://www.republi kasrpska.net/predsjednici/biljana-plavsic/, [dostęp: 06.09.2016].
} 
roku obroniła doktorat $\mathrm{z}$ botaniki ze specjalizacji fitopatologia (choroby roślin) ${ }^{7}$. W 1971 roku wyjechała na stypendium w ramach programu Fulbrighta do BoyceThompson Institute w Nowym Jorku. Po powrocie do Sarajewa poświęciła się dalszej karierze naukowej, uzyskując tytuł profesora i pełniąc funkcję dziekana Wydziału Przyrodniczo-Matematycznego Uniwersytetu w Sarajewie ${ }^{8}$. W 2009 roku Senat tegoż Uniwersytetu ${ }^{9}$ postanowił pozbawić B. Plavšić tytułów naukowych, a także wszystkich praw i przywilejów akademickich. Zdaniem akademików, w swych działaniach politycznych złamała ona podstawowe zasady etyczno-moralne, którymi powinien legitymować się pracownik nauki ${ }^{10}$. W następstwie tej decyzji dane B. Plavšić zostały usunięte $\mathrm{z}$ ewidencji Uniwersytetu sarajewskiego ${ }^{11}$.

W polityce bośniackiej B. Plavšić pojawiła się na początku lat dziewięćdziesiątych XX wieku. W połowie lipca 1990 roku, wraz z Momčilo Krajišnikiem i Nikolą Koljeviciem (który miał ją przekonać do działalności politycznej ${ }^{12}$ ) została ona członkinią nowo założonej Serbskiej Partii Demokratycznej (Srpska Demokratska Stranka, SDS), kierowanej przez R. Karadžicia ${ }^{13}$. W strukturach tej partii zrobiła karierę, szybko awansując do najwyższych władz w państwie. W połowie listopada 1990 roku w BiH odbyły się pierwsze demokratyczne wybory do parlamentu, władz gminnych i Prezydium republiki. W ich wyniku partie narodowe - serbska SDS, muzułmańska Partia Akcji Demokratycznej (Stranka Demokratske Akcije, SDA) i Chorwacka Wspólnota Demokratyczna BiH (Hrvatska Demokratska Zajednica; HDZ BiH) zdominowały scenę wewnętrzną państwa, ostatecznie wyznaczając mapę podziałów etniczno-politycznych. W nowym siedmioosobowym Prezydium BiH, którego przewodniczącym został lider SDA Alija Izetbegović, B. Plavšić zajęła jedno z dwóch miejsc przeznaczonych dla reprezentacji serbskiej (razem z N. Koljeviciem) ${ }^{14}$. Funkcję tę pełniła do

${ }^{7}$ B. Plavšić poszła w ślady swojego ojca, który również był biologiem. C.S. Lilly, J.A. Irvine, op. cit., s. 267.

${ }^{8}$ M. Evangelista, Gender, Nationalism and War. Conflict on the Movie Screen, New York 2011, s. 106.

${ }^{9}$ W 1992 roku władze Republiki Serbskiej podjęły decyzję, że Uniwersytet we Wschodnim Sarajewie będzie sukcesorem Uniwersytetu w Sarajewie, który opuściła znaczna liczba naukowców i studentów narodowości serbskiej.

${ }^{10}$ Plavšićeva bez akademiskih prava u Sarajevu -http://www.novosti.rs/vesti/naslovna/drustvo/aktuelno.290.html:255472-Plavsiceva-bez-akademskih-prava-u-Sarajevu, [dostęp: 06.09.2016].

${ }^{11}$ Egzemplarze dysertacji doktorskiej B. Plavšić wciąż są dostępne w bibliotece uniwersyteckiej w Belgradzie i Maticy Serbskiej w Nowym Sadzie. Jako ciekawostkę można zaznaczyć, że w systemie bibliotecznym widnieje ona pod nazwiskiem B. Plavšić-Banjac, choć najczęściej wspomina się, że była niezamężna. Międzynarodowy Trybunał Karny dla byłej Jugosławii (ICTY) podaje, że w latach 1963-1976 była w związku małżeńskim z prawnikiem Žarko Banjacem.

12 C. Rogel, The breakup of Yugoslavia and its aftermath, United States of America 2004, s. 134.

${ }^{13}$ S.L. Szczesio, Droga ku wojnie - sytuacja w Bośni i Hercegowinie w latach 1990-1992, w: Batkany w XX i XXI wieku. Historia - Polityka - Kultura. Materiaty z konferencji „Poznać Batkany” Torun, 29 maja 2009 roku, red. H. Stys, Sz. Sochacki, Torun 2009, s. 25.

${ }^{14}$ D. Wybranowski, Między niepodległościa a dezintegracją. Bośnia i Hercegowina w XX i XXI wie$k u$, Szczecin 2011, s. 185. 
początku kwietnia 1992 roku ${ }^{15}$. Na marginesie zaznaczmy, że w tym samym czasie na czele parlamentu BiH stał inny serbski działacz, M. Krajišnik ${ }^{16}$.

Partie narodowe w BiH prezentowały odmienne stanowiska co do przyszłości państwa. SDA i HDZ BiH dążyły do uchwalenia niepodległości, czemu sprzeciwiała się SDS, która optowała za zachowaniem federacji jugosłowiańskiej. Muzułmanie (od 1993 roku określani jako Boszniacy) i Chorwaci starali się przeforsować Deklaracje o suwerenności państwowej i niepodzielności Republiki Bośni i Hercegowiny (Deklaracija o državnoj suverenosti i nedjeljivosti Republike Bosne i Hercegovine). Do największej polaryzacji stanowisk w związku z tym dokumentem doszło podczas sesji parlamentarnej z 14 na 15 października 1991 roku. Serbowie w akcie protestu wobec próby uchwalenia Deklaracji opuścili obrady. Mimo że M. Krajišnik oficjalnie zamknął wówczas sesję parlamentarną, członkowie SDA i HDZ BiH przyjęli odrzucany przez Serbów dokument ${ }^{17}$. Od tej chwili strona serbska zmierzała do secesji z BiH, z kolei Boszniacy i Chorwaci dążyli do tego, aby bośniacka niepodległość została uznana na arenie międzynarodowej. B. Plavšić, jako przedstawicielka społeczności serbskiej w Prezydium BiH wyrażała stanowisko SDS, ostro krytykując działania niepodległościowe strony muzułmańsko-chorwackiej. Gdy na początku kwietnia 1992 okazało się, że ogłoszona miesiąc wcześniej niepodległość BiH została uznana przez większość państw ${ }^{18}$, B. Plavšić postanowiła opuścić struktury Prezydium. Udała się do Pale, gdzie znajdowały się organa władzy tzw. Republiki Serbskiej ${ }^{19}$.

W omawianym okresie różne wypowiedzi B. Plavšić trafiały do przekazów o charakterze propagandowym, obliczonych na potęgowanie nienawiści etnicznej, rozpowszechnianych przez media stojące po przeciwnych stronach. Władze RS przekonywały Serbów, że życie z innymi narodami w BiH było nie do zaakceptowania i stanowiło dla nich śmiertelne zagrożenie. Zachowania mające na celu integrację międzyetniczną zostały uznane za wymierzone w Serbów ${ }^{20}$. Także B. Plavšić uważała, że obywatelska, wieloetniczna $\mathrm{BiH}$ była niebezpieczna dla żywiołu serbskiego. Jej zdaniem, funkcjonowanie w takim państwie groziło wyjałowieniem serbskiej tożsamości narodowej. RS, stworzoną w opozycji wobec działań strony muzułmańsko-chorwackiej, B. Plavšić uznawała za byt gwarantujący i chroniący prawa Serbów. Świadczyła o tym chociażby jej wypowiedź na forum parlamentu RS z 9 stycznia 1992 roku, w dniu powołania quasi państewka:

${ }^{15}$ B.A. Cook, op. cit., s. 470.

${ }^{16}$ K. Krysienel, Ewolucja systemu politycznego Bośni i Hercegowiny w latach 1990-1995, w: Batkany Zachodnie między przeszłością a przyszłościa, red. P. Chmielewski, S.L. Szczesio, Łódź 2013, s. 230 .

17 Ibidem, s. 231-232.

18 S.L. Szczesio, op. cit., s. 35, 39.

${ }^{19}$ K. Krysienel, op. cit., s. 234.

${ }^{20}$ I. Lovrenović, Bosnia. A Cultural History, przeł. S. Wild Bičanić, New York 2001, s. 195. 
Żaden Serb, dla którego tożsamość narodowa jest ważna, nie może zgodzić się na to, aby zostać przekształconym w bezimiennego obywatela Bośni i Hercegowiny, Bośni i Hercegowiny, w której wszyscy obywatele byliby tacy sami, na przyktad zieloni (... $)^{21}$.

Przedstawiona powyżej wizja ,zielonych obywateli” odnosiła się do rzekomego niebezpieczeństwa zdobycia przez Muzułmanów bośniackich dominacji w BiH. B. Plavšić oskarżała muzułmańskich liderów, że chcieli narzucić wszystkim bośniackim chrześcijanom zasady państwa wyznaniowego. W dalszej części wspomnianej wypowiedzi zawarła ona następujące spostrzeżenie: teraz funkcjonuje nie Mała Serbia, Mała Czarnogóra, Mała Chorwacja, ale Wielka Bośnia i Hercegowina $i$ to Wielka Bośnia i Hercegowina pod realna władza jednego narodu i jednego człowie$k a^{22}$. Żelazna Dama nawiązała w ten sposób do muzułmańskiego promotora bośniackiej niezależności A. Izetbegovicia, który od lat sześćdziesiątych XX wieku działał na rzecz ugruntowania politycznych wpływów islamu w $\mathrm{BiH}$, za co kilka razy trafił do więzienia w czasach komunistycznych. W swoich publikacjach propagował on utworzenie państwa odwołującego się do zasad Koranu. Co więcej, za niemożliwe uważał on wówczas pokojowe ułożenie stosunków między muzułmanami a wyznawcami innych religii w ramach tego samego organizmu państwowego 23 .

B. Plavšić powielała hasła antymuzułmańskie w mediach i podczas wystąpień publicznych. Bez wątpienia propagowała serbską propagandę wojenną. Na przykład, w 1993 roku w swojej prowojennej argumentacji zawarła teorie akcentujące konieczność zadbania o czystość rasową w Bośni. Głosiła, że Muzułmanie byli zdeformowani genetycznie, a potomstwo pochodzące z mieszanych małżeństw serbsko-muzułmańskich stanowiło degenerację serbskości. Bez wątpienia, B. Plavšić mogła w ten sposób usprawiedliwiać zbrodnie przeciwko ludności cywilnej, głównie muzułmańskiej, dokonywane przez oddziały serbskie w imię polityki czyszczenia etnicznego. Działania te uznawała za zjawisko naturalne, jej zdaniem konieczne dla eliminacji zagrożenia, utożsamianego z etniczno-religijną heterogenicznością terytorium bośniackiego $^{24}$. Powyższe wypowiedzi, nacechowane argumentacją biologiczno-rasistowską, do tej pory są przywoływane jako przykład serbskiego szowinizmu, stojącego za krwawymi wydarzeniami wojny w BiH.

W artykule 2. Konstytucji samozwańczej Republiki Serbskiej zapisano, że Terytorium Republiki tworza (...) także terytoria, na których w trakcie II wojny światowej popetniono ludobójstwo na członkach narodu serbskiego ${ }^{25}$. Nawiązania do czasów II wojny światowej, która stanowi jeden z kluczowych odwołań w serbskim ima-

${ }^{21}$ R. Donia, Iz skupštine Republike Srpske 1991-1996. Izvodi iz izlaganja poslanika skupštine Republike Srpske kao dokazni materijal na Međunarodnom Krivičnom Tribunalu u Hagu, Sarajevo-Tuzla 2012, s. 34.

22 Ibidem.

${ }^{23}$ D. Wybranowski, op. cit., s. 162-164 oraz E. Bujwid-Kurek, Rola Alii Izetbegovicia w ksztaltowaniu muzutmańskiej wspólnoty narodowej Bośni i Hercegowiny, „Slavia Medirionalis” 11 (2011), s. 176179.

${ }^{24}$ M. Evangelista, op. cit., s. 106.

${ }^{25}$ K. Krysienel, op. cit., s. 239. 
ginarium kulturowym, były integralnym elementem ówczesnej rzeczywistości społeczno-politycznej w RS. B. Plavšić wielokrotnie podejmowała w swojej działalności publicznej wątek serbskich cierpień wojennych, zadanych przez faszystów i ustaszy, których utożsamiała ze współczesnymi Chorwatami i Muzułmanami bośniackimi (Boszniakami). Te nawiązania miały pełnić rolę swoistych ostrzeżeń dla bośniackich Serbów, aby nie pozwolili na „powtórkę z historii””26. Do czasów wojny z lat 1941-1945 B. Plavšić nawiązała także w mowie końcowej, wygłoszonej podczas procesu przed Międzynarodowym Trybunatem Karnym dla byłej Jugosławii (ICTY). Stwierdziła wówczas, że na początku lat dziewięćdziesiątych XX wieku bośniaccy Serbowie wpadli w - jak to określiła - obsesję. Obserwując nawarstwiające się sprzeczności etniczne, zinterpretowali je jako zagrożenie. Zdaniem B. Plavšić, nie chcieli ponownie stać się ofiarami z rąk sąsiadów o innym wyznaniu, dlatego sami przyjęli agresywną postawę ${ }^{27}$.

Oprócz wyrazistych wystąpień publicznych, B. Plavšić zaistniała w medialnej przestrzeni konfliktu bośniackiego także poprzez doniesienia z początku kwietnia 1992 roku o tzw. „,pocałunku śmierci”28. Wydarzenie to było związane z atakiem Serbskiej Gwardii Ochotniczej (Srpska Dobrovoljačka Garda) na wschodnią BiH. Była to jedna z grup paramilitarnych znana pod nazwą Tygrysy Arkana (Arkanovi Tigrovi), od przydomka głównego dowódcy oddziałów Željka Ražnatovicia „Arkana”. Gdy na początku kwietnia 1992 roku jego oddziały przejęły kontrolę nad miejscowością Biljeljina, B. Plavšić, wtedy jeszcze członkini Prezydium BiH, udała się tam na prośbę A. Izetbegovicia, aby zaapelować o zaprzestanie mordów na miejscowej ludności ${ }^{29}$. Nie tylko tego nie uczyniła, ale - jak opisywano to później w gazetach - ominęła ciała zabitych Boszniaków, podeszła do serbskiego dowódcy i pocałowała go w policzek. Jej gest był komentowany jako aprobata przedstawicielki elit polityczno-wojskowych RS dla zbrodniczej aktywności serbskich sił paramilitarnych na terenie $\mathrm{BiH}^{30}$.

Po opuszczeniu Prezydium BiH, B. Plavšić kontynuowała działalność polityczną, pełniąc wysokie funkcje w strukturach RS. Została mianowana wiceprezydentem. Działała w ramach kolegialnego Prezydium RS, wraz z przewodniczącym R. Karadžiciem i drugim wiceprezydentem Nikolą Koljeviciem. Z racji swojego urzędu weszła w skład Naczelnego Dowództwa Sił Zbrojnych Republiki Serbskiej (Vrhovna

${ }^{26}$ M. Rekść, Polityka historyczna jako instrument manipulacji przestrzeniami zbiorowymi na przykładzie Bałkanów, w: Bałkany w XX i XXI wieku. Historia-Polityka-Kultura. Materialy z konferencji „Poznać Batkany”, Toruń, 29 maja 2009 roku, red. H. Stys, Sz. Sochacki, Torun 2009, s. 81-83.

27 J. Subotić, The Cruelty of False Remorse: Biljana Plavšić at The Hague, "Southeastern Europe", 2012, nr 36, s. 43-44. Być może częste odnoszenie się B. Plavšić do spraw związanych z II wojną światową wynikało z traumatycznych doświadczeń jej rodziny podczas tego konfliktu Jej rodzina w wyniku tego konfliktu straciła ponad 30 członków. C.S. Lilly, I.A. Irvine, op. cit., s. 267.

${ }^{28}$ Biljana Plavšić: Želim da me svi zaborave... - http://www.radiosarajevo.ba/vijesti/bosna-i-hercego vina/biljana-plavsic-zelim-da-me-svi-zaborave/195918, [dostęp: 06.09.2016].

${ }^{29}$ A. Krupić, Žene ratni zločinci s posebnim osvrtom na žene izvršioce ratnih zločina u Bosni i Hercegovini 1992-1995, Sarajevo 2010, s. 136.

${ }^{30}$ Ch. Stephen, Judgement Day. The Trial of Slobodan Milošević, London 2004, s. 67-68. 
komanda Oružanih snaga Republike Srpske) ${ }^{31}$ i była członkinią Rady ds. bezpieczeństwa narodowego (Savjet za nacionalnu bezbjednost). Pełnienie tych funkcji oznaczało dostęp B. Plavšić do najważniejszych informacji o działaniach sił bośniackich Serbów na polu walk w BiH. Nie ulega wątpliwości, że wiedziała ona o zbrodniach dokonywanych na ludności cywilnej przez serbskie oddziały wojskowe i paramilitarne, tym bardziej, że wielokrotnie wizytowała żołnierzy na froncie ${ }^{32}$. Według różnych relacji, B. Plavšić cieszyła się dużym szacunkiem wśród walczących Serbów. Niektórzy mieli nawet grawerować jej imię na swojej broni, nazywali ją Cesarzowa lub Caryca. Wedle jednej z plotek, Arkan, który w ramach prania pieniędzy pochodzących z działalności przestępczej otwierał w Belgradzie różnego rodzaju przybytki - restauracje czy kawiarnie, jednej z nich nadał nazwę „Biljana”33.

Ciekawy wątek politycznej aktywności B. Plavšić z czasu konfliktu zbrojnego w BiH, stanowią jej kontakty z dowódcami serbskich formacji paramilitarnych, którzy współdziałali z oddziałami Serbów bośniackich. Kwestia ta nie pojawiła się jak dotąd w opracowaniach dotyczących wojny bośniackiej, ale jej obecność można wywnioskować na podstawie transkrypcji wypowiedzi B. Plavšić w parlamencie RS z końca października 1992 roku. B. Plavšić przyznała wówczas, że zwróciła się do ochotników gotowych walczyć w Bośni o serbskość (srpstvo). Jednocześnie zaprzeczała jakoby „zaproszenie” było zwrócone do oddziałów o nierzadko przestępczym charakterze, wykazujących szczególne okrucieństwo podczas walk toczonych w Chorwacji w $1991 \mathrm{roku}^{34}$. Tymczasem otrzymanie pisma z takim właśnie zaproszeniem potwierdził podczas procesu przed ICTY nacjonalistyczny polityk z Serbii i zarazem dowódca jednej z takich grup Vojislav Šešelj. Dodajmy, że przy tej okazji z drwiną użył on określenia „Caryca”35. Można domniemywać, że B. Plavšić miała pełną świadomość, jakie cele wojenne przyświecały władzom RS. Wspierała je z przekonaniem, wręcz z żarliwością.

Prowojenne stanowisko serbskiej Żelaznej Damy było widoczne nawet wtedy, gdy słabła współpraca polityczna między RS a Belgradem - kością niezgody były proponowane rozwiązania pokojowe, forsowane przez wspólnotę międzynarodową. Gdy prezydent Federacyjnej Republiki Jugosławii (FRJ) Slobodan Milošević opowiedział się w połowie 1993 roku za przyjęciem pokojowego planu Vance'a-Owena, B. Plavšić nazwała go zdrajcą interesu serbskiego ${ }^{36}$. Demonstracyjnie nie podała mu ręki, gdy w tym samym roku odwiedził Pale, chcąc przekonać bośniackich Serbów do tej propozycji ${ }^{37}$.

${ }^{31}$ Biljana Plavšić, w: Republika Srpska ... op. cit.

${ }^{32}$ A. Krupić, op. cit., s. 135.

${ }^{33}$ C.S. Lilly, J.A. Irvine, op. cit., s. 268-269.

${ }^{34}$ R. Donia, op. cit., s. 74.

${ }^{35}$ Vojislav Šešelj o Biljani Plavšič - https://www.youtube.com/watch?v=9rcf3sM2Sso, [dostęp: 24.09.2016].

${ }^{36}$ P.R. Bartrop, A Biographical Encyclopedia of Contemporary Genocide: Portraits of Evil and Good, United States of America 2012, s. 271.

${ }^{37}$ A. LeBor, Milosevic. A Biography, Great Britain 2002, s. 233. 
Należy zwrócić uwagę, że wraz z komplikowaniem się sytuacji politycznej, w ramach RS dały o sobie znać głębokie podziały. Frustrację niezadowolonych Serbów bośniackich, wywodzących się z różnych środowisk, potęgowały problemy ekonomiczne, spowodowane przez funkcjonowanie czarnego rynku zorientowanego na potrzeby wojenne. Na przykład, we wrześniu 1993 roku Banja Luka stała się areną tygodniowego buntu wojskowych, którzy żądali zaprzestania przemytu i sprzedaży po zawyżonych cenach $\mathrm{m}$.in. alkoholu, paliwa i papierosów. Na procederze tym bogaciła się elita rządząca w RS, negatywnie odbijało się to na morale wojska i społeczeństwa $^{38}$. W tych okolicznościach, w ramach partii rządzącej (SDS) doszło do sporu co do dalszych działań politycznych oraz zbrojnych. Utworzyły się dwa bloki, skrajny (wojenny) w Pale i umiarkowany w Banja Luce, który stopniowo wyrastał na ośrodek opozycyjny wobec głównego nurtu w SDS. Warto zaznaczyć, że już w 1991 roku Banja Luka stanowiła swoistą bazę dla ruchu starającego się zdystansować wobec oficjalnej polityki partii rządzącej ${ }^{39}$. Dwa lata później środowisko polityków z Pale, które w największym stopniu czerpało profity z czarnego rynku, forsowało kontynuację scenariusza wojennego w BiH. Przedstawiciele tzw. bloku umiarkowanego wzywali do działań koncyliacyjnych i podjęcia współpracy międzynarodowej w kierunku wygaszenia działań zbrojnych. Ówczesna opozycja wewnętrzna w ramach SDS była wspierana przez S. Miloševicia ${ }^{40}$. Gdy środowisko Serbów bośniackich odrzuciło plan Grupy Kontaktowej, zaprezentowany w 1994 roku, prezydent FRJ postanowił wprowadzić sankcje ekonomiczne przeciwko RS. Jej wojska nie były w stanie prowadzić skutecznych działań wojennych bez dostaw z FRJ ${ }^{41}$. Co więcej, przeciwko R. Karadžiciowi „zbuntować się” miał nawet R. Mladić. Był on zaniepokojony pogłębiającą się walką polityczną w ramach SDS. Oczekiwał od prezydenta RS klarownych decyzji w kierunku profesjonalizacji wojska i pacyfikowania partykularnych aspiracji, prezentowanych przez poszczególne środowiska polityczne ${ }^{42}$.

Postępująca izolacja geopolityczna i ekonomiczna RS, a także dramatyczna sytuacja gospodarcza zmusiły Serbów bośniackich do rozmów. Pozycja polityczna lidera Serbów bośniackich osłabła, gdy w połowie 1996 roku musiał zrezygnować z działalności politycznej, wraz wystosowaniem przeciwko niemu i R. Mladiciowi międzynarodowego listu gończego przez ICTY. Wcześniej, na podstawie traktatu daytońskiego ustąpił on ze stanowiska prezydenta RS. R. Karadžić niechętnie podporządkowywał się tym decyzjom. Chcąc złagodzić frustrację wyrażaną przez niegdysiejszego lide-

${ }^{38}$ K. Bugarel, Bosna. Anatomija rata, przeł. J. Stakić, Beograd 2004, s. 180.

39 D. Wybranowski, Armia Republiki Serbskiej w Bośni (1992-1995) - geneza, struktura i pierwsze lata istnienia, w: Bałkany Zachodnie... op. cit., s. 155. Jako ciekawostkę możemy podać fakt, że jeśli przyjrzymy się geografii wyborczej w Republice Serbskiej to zobaczymy, że południe z Pale głosuje na SDS, a północ z Banja Luką na partię Milorada Dodika.

${ }^{40}$ K. Krysienel, W cieniu Dayton. Bośnia i Hercegowina między etnokracją i demokracją konsocjonalna, Warszawa 2012, s. 210.

${ }^{41}$ M. Kuczyński, Krwawa Europa. Konflikty zbrojne i punkty zapalne w latach 1990-2000. Tto historyczne i stan obecny, Warszawa 2001, s. 212, 217.

${ }^{42}$ K. Bugarel, op. cit., s. 187-189. 
ra RS i jego współpracowaników, S. Milošević, który od czasu negocjacji w Dayton reprezentował na zewnętrz interesy Serbów bośniackich ${ }^{43}$, doprowadził do zawarcia swoistego kompromisu w sprawie prezydentury. Na tej podstawie R. Karadžić namaścił na tymczasowego prezydenta RS B. Plavšić. Wybór nie był przypadkowy, R. Karadžić zamierzał utrzymać wpływy we władzach RS, lokując tam swoich popleczników. Już wcześniej, w maju 1996 roku, doprowadził on do dymisji premiera RS Rajko Kasagicia, który zdaniem lidera Serbów bośniackich wykazywał nadmierną skłonność do koncyliacji ze wspólnotą międzynarodową i liderami innych grup narodowych z BiH. Następcą R. Kasagicia został Gojko Kličković, związany z tzw. frakcją z Pale ${ }^{44}$. Ustępujący prezydent RS wierzył, że B. Plavšić, jego bliska współpracowniczka z czasów wojennych, będzie kontynuować jego dotychczasową politykę. Ponoć R. Karadžić uznawał ją za polityka o radykalnych poglądach i był przekonany co do jej lojalności ${ }^{45}$.

Taktyka polityczna, podjęta przez B. Plavšić w okresie powojennym do dziś dzieli badaczy. Chcąc przeciwdziałać przestępczości związanej z osobami z bliskiego kręgu R. Karadžić, zacieśniła ona kontakty ze środowiskiem politycznym z Banja Luki i podjęła współpracę z siłami międzynarodowymi. Krok ten był dla wielu osób zaskoczeniem. Serbska Żelazna Dama uchodziła w pełni lojalną wobec R. Karadžicia, tymczasem po zakończeniu wojny nie szczędziła słów publicznej krytyki kolegom z SDS ${ }^{46}$. Jak napisał Krzysztof Krysienel, Plavšić, przez dlugi czas uważana za polityka niezwykle radykalnego, głoszaca skrajne nacjonalistyczne poglady, dokonywata ryzykownej politycznej wolty. Było to o tyle zaskakujace, że przez lata stała u boku Karadžicia i blisko z nim wspótpracowała, petniąc funkcje wiceprezydent Republiki Serbskiej ${ }^{47}$. Zdaniem innych badaczy, Roberta Bideleux i Iana Jeffiresa, postanowiła ona podjąć współpracę ze środowiskami umiarkowanymi oraz międzynarodowymi, aby osłabić wydźwięk oskarżeń o zbrodnie wojenne, formułowanych przez ICTY ${ }^{48}$. Najczęściej metamorfozę polityczną B. Plavšić uznaje się za nieszczerą i koniunkturalną. Osoba wywodząca się ze środowiska politycznego R. Karadzicia nie mogła być $\mathrm{w}$ pełni wiarygodna $\mathrm{w}$ roli liderki społeczności Serbów bośniackiej w zmienionej rzeczywistości politycznej ${ }^{49}$. Z drugiej strony, warto przytoczyć opinię C. Bildta. Uznał on, że B. Plavšić stopniowo dojrzewała do zmiany nastawienia wobec spraw RS. Ewolucja jej postawy miała nastąpić jeszcze podczas wojny, wraz z postępującą dyskredytacją środowiska popierającego rozwiązania zbrojne ${ }^{50}$.

\footnotetext{
${ }^{43}$ Pod koniec września 1995 roku parlament RS przekazał S. Miloševiciowi mandat na reprezentowanie Serbów bośniackich w negocjacjach pokojowych. K. Bugarel, op. cit., s. 113.

${ }^{44}$ R. Bideleux, I. Jeffires, The Balkans. A post-Communist history, New York 2007, s. 360-361.

${ }^{45}$ P.R. Bartrop, op. cit., s. 271.

${ }^{46}$ B.A. Cook, op. cit., s. 470.

${ }^{47}$ K. Krysienel, W сіеniu Dayton ... op. cit., s. 209-211.

${ }^{48}$ R. Bideleux, I. Jeffries, op. cit., s. 372.

${ }^{49}$ M. Parish, A Free City in the Balkans. Reconstructing a Divided Society in Bosnia, New York 2010, s. 104-105.

${ }^{50}$ C. Bildt, op. cit., s. 335.
} 
Pod koniec 1996 roku., jako tymczasowa prezydent, B. Plavšić doprowadziła do dymisji R. Mladicia ze struktur wojskowych RS i jednoczenie przejęła ona funkcję Naczelnego Wodza wojsk Serbów bośniackich ${ }^{51}$. Podkreślała, że dymisja R. Mladicia była konieczna, ponieważ znalazł się on na liście oskarżonych przez ICTY. Z drugiej strony, prezydent RS w wywiadach prasowych pozytywnie oceniała jego działalność z czasów wojny, uznając go za serbskiego patriotę ${ }^{52}$.

B. Plavšić wygrała powojenne wybory prezydenckie, przeprowadzone we wrześniu 1996, uzyskując wynik 59,19\% (wiceprezydentem został Dragoljub Mirjanović). Duży wpływ na jej zwycięstwo miał fakt, że nadal była kojarzona z R. Karadžiciem, który cieszył się estymą bohatera narodowego wśród serbskich wyborców. W tym samym czasie przeprowadzone zostały także wybory parlamentarne, w których SDS zdobyła ponad połowę miejsc w Zgromadzeniu Narodowym RS i mogła rządzić samodzielnie ${ }^{53}$. B. Plavšić starała się zachować bezpieczny dystans wobec radykalnych polityków z parlamentu RS, a także wobec reżimu S. Miloševicia ${ }^{54}$. I tak, w lutym 1997 roku odmówiła udania się do Belgradu na podpisanie umowy ustanawiającej wzajemne stosunki między Republiką Serbską w BiH a FRJ. Dodajmy, że umowa została wynegocjowana przez M. Krajišnika, członka Prezydium BiH (od 1996 roku), uznawanego za współpracownika R. Karadžicia i oponenta prezydent RS. Układ nie wszedł w życie, ponieważ został zablokowany przez parlament BiH. Przy tej okazji, jak pisze Szymon Sochacki, Prezydent RS okazała się być politykiem ambitnym. Nie chciała grać roli marionetki Karadžicia i wyczekawszy odpowiedni moment wystapiła przeciwko swoim niedawnym współtowarzyszom ${ }^{55}$.

Międzynarodowe siły stabilizacyjne podjęły współpracę z B. Plavšić w nadziei, że będzie ona w stanie tonować napięte nastroje społeczne w RS i ograniczy wpływy przeciwników ładu pokojowego. Wypowiadając wojnę dotychczasowym powiązaniom politycznym i gospodarczym, prezydent napotkała jednak zdecydowany opór ze strony SDS, nadal dominującej w parlamencie. Sytuacja polityczna B. Plavšić skomplikowała się pod koniec czerwca 1996 roku, gdy związany z SDS premier rządu RS odmówił zdymisjonowania Ministra Spraw Wewnętrznych Dragana Kijaca (w jej ocenie poplecznika Karadžicia) ${ }^{56}$. W odpowiedzi, prezydent ogłosiła rozwiązanie Zgromadzenia Narodowego, co Trybunał Konstytucyjny Republiki Serbskiej uznał za akt bezprawny. Zaistniały pat polityczny częściowo zdołano rozwiązać w Belgradzie, gdzie obok siebie zasiedli B. Plavšić, M. Krajišnik i S. Milošević. Na mocy podpisa-

51 Więcej: D. Wybranowski, Proces redukcji i kres istnienia Armii Republiki Serbskiej w Bośni (1995-2006), „Bezpieczeństwo. Teoria i Praktyka” 2012, t. 8, nr 3, s. 93.

52 M. Marković, Biljana Plavšić: Nemam nijedne ružne reči o Mladiću - http://www.novosti.rs/ve sti/naslovna/dosije/aktuelno.292.html:332500-Biljana-Plavsic-Nemam-nijedne-ruzne-reci-o-Mladicu, [dostęp 24.09.2016].

53 Sz. Sochacki, Bośnia i Hercegowina 1995-2012. Studium politologiczne, Toruń 2015, s. 181182.

54 T. Gallagher, The Balkans after the Cold War. From Tyranny to Tragedy, London 2003, s. 185.

55 Sz. Sochacki, op. cit., s. 183-184.

56 R. Bideleux, I. Jeffires, op. cit., s. 365-366. 
nej wówczas tzw. umowy belgradzkiej ustalono, że we wrześniu 1997 roku zostaną przeprowadzenie wybory parlamentarne i prezydenckie w Republice Serbskiej oraz wybrany będzie serbski reprezentant w Prezydium BiH. Postanowienia umowy zrealizowano połowicznie, przeprowadzając jedynie wybory do parlamentu ${ }^{57}$. W tym samym czasie nastąpił ostateczny rozwód między B. Plavšić a SDS. Prezydent postanowiła wystąpić z partii (według niektórych relacji została z niej usunięta ${ }^{58}$ ) i założyła własne ugrupowanie o nazwie Serbski Związek Narodowy (Srpski Narodni Savez, SNS $)^{59}$.

Politycy związani z Pale ostro atakowali B. Plavšić, zarzucając jej zdradę interesów narodowych. W ich ocenie, prezydent przyzwoliła na międzynarodowy protektorat w RS. Zarzucano jej między innymi, że doprowadziła do przyjęcia prawa wyborczego zasugerowanego przez Organizację Współpracy i Bezpieczeństwa w Europie (OBWE). Szczególnie krytykowano przepisy umożliwiające głosowanie w wyborach samorządowych na podstawie miejsca zamieszkania z 1991 roku. Wielu bośniackich Serbów odczytało to jako ciche przyzwolenie na odbudowę struktur wieloetnicznych na terenie RS. W opinii samej B. Plavšić, za atakami na jej osobę stał R. Karadžić, sterujący środowiskiem, które nadal kontestowało ład daytoński. Prawdopodobnie za jego namową rada partii doprowadziła w połowie 1997 roku do zwołania nadzwyczajnej sesji parlamentu pod nieobecność prezydent, która natenczas przebywała w Wielkiej Brytanii ${ }^{60}$. Ta nazwała działania parlamentu próbą zamachu stanu i próbowała jak najszybciej wrócić do RS. Zdaniem obserwatorów, na osłabieniu pozycji B. Plavšić szczególnie zależało M. Krajišnikowi, który był wspierany przez S. Milosevicia ${ }^{61}$.

Sytuacja w połowie 1997 roku była napięta i niebezpieczna: w dzień po utworzeniu przez prezydent RS jej własnej partii w Banja Luce i Doboju wybuchły bomby $^{62}$. Wydarzenia te doprowadzily do powołania specjalnej grupy wsparcia, której celem była ochrona B. Plavšić,. Formacja ta działała w ramach międzynarodowych sił stabilizacyjnych (SFOR). Jak stwierdził Maciej Kuczyński: bez wojsk SFOR Biljana Plavšić poniostaby szybka porażkę w starciu z Karadžiciem i Krajišnikiem ${ }^{63}$. Wsparcie ze strony sił międzynarodowych pozwoliło jej osiągnąć pewne sukcesy polityczne, godzące w pozycję R. Karadžicia i współpracowników. Takim wydarzeniem

${ }^{57}$ Sz. Sochacki, op. cit., s. 184.

${ }^{58}$ I. Oliver, War \& Peace in the Balkans. The Diplomacy of Conflict in the Former Yugoslavia, New York 2005, s. 244.

${ }^{59}$ R. Bideleux, I. Jeffires, op. cit., s. 366.

${ }^{60}$ Istnieją dwie interpretacje co do celu jej wizyty zagranicznej. Wedle jednej relacji pojechała do Wielkiej Brytanii, aby złożyć wizytę tamtejszej mniejszości serbskiej. Ian Oliver zaś wskazuje, że B. Plavšić udała się tam, aby szukać wsparcia dla prowadzonej przez siebie polityki od rządu brytyjskiego. I. Oliver, op. cit., s. 217.

${ }^{61}$ Ian Oliver wprost zaznacza, że wiedzieli oni, iż nie moga jej po prostu zabić (...), ale musieli ja zatrzymać. Stanowiła bowiem istotne zagrożenie dla ich lukratywnych czarnych interesów. I. Oliver, op. cit., s. 217.

${ }^{62}$ R. Bideleux, I. Jeffries, op. cit., s. 366.

${ }^{63}$ M. Kuczyński, op. cit., s. 244. 
było ujawnienie nielegalnej działalności spółki „Javnost”, której właścicielką była małżonka Karadžicia, Ljiljana Zelen-Karadžić6 ${ }^{64}$.

Za poczynaniami B. Plavšić ciągnęła się kwestia jej odpowiedzialności za działania władz Republiki Pale w ponurych czasach wojny bośniackiej, mimo to dla przedstawicieli międzynarodowych sił stabilizacyjnych stała się ona jednym z najważniejszych gwarantów procesu pokojowego w $\mathrm{BiH}^{65}$. $\mathrm{Z}$ drugiej strony, niepokojące były wypowiedzi prezydent RS wymierzone w wieloetniczną i związkową formułę państwa. B. Plavšić nadal przestrzegała przed roztopieniem się Serbów w nazbyt jej zdaniem zuniformizowanej Bośni i Hercegowinie. Swoją rolę przedstawiała ona w kategoriach patriotycznego obowiązku. Chodziło o uratowanie narodu serbskiego przed katastrofą, a także ukrócenie działalności nacjonalistów, nieuznających zasad ładu daytońskiego ${ }^{66}$. Mimo to wielu Serbów zarzucało jej zaprzedanie się mocarstwom zachodnim a nawet zdradę narodową ${ }^{67}$.

Pod koniec 1997 roku SDS utraciła znaczący wpływ na władzę. Wobec problemów z wyłonieniem stabilnej koalicji parlamentarnej (po wyborach przedterminowych ustalonych w ramach tzw. porozumienia belgradzkiego), Wysoki Przedstawiciel w BiH Carlos Westendorp (1997-1999) ${ }^{68}$ wskazał na szefa rządu Milorada Dodika. Zdaniem niektórych badaczy, prezydent miała osobiście sugerować $\mathrm{C}$. Westendorpowi tę kandydaturę, argumentując, że przełamie ona pat związany z niemożnością wyłonienia stabilnej większości rządowej w parlamencie ${ }^{69}$. Istotnie niewielka partia M. Dodika (Związek Niezależnych Socjaldemokratów, następnie Partia Niezależnych Socjaldemokratów; Stranka Nezavisnih Socijaldemokrata; SNSD) weszła wkrótce do koalicji rządowej z prezydenckim ugrupowaniem $\mathrm{SNS}^{70}$. B. Plavšić oczekiwała, że M. Dodik będzie prowadzić walkę z establishmentem SDS, które miało wiele do powiedzenia w administracji wewnętrznej. M. Dodik dał się poznać jako krytyk R. Karadžicia jeszcze podczas konfliktu zbrojnego, przez co zagranica dawała mu pewien polityczny kredyt. Tak jak B. Plavšić, traktował on powojenną RS jako twór polityczny, który mimo wszystkich niedoskonałości zapewniał bośniackim Serbom podstawową ochronę ${ }^{71}$.

${ }^{64}$ S.P. Ramet, The Three Yugoslavias. State-Building and Legimation, 1918-2015, United States of America 2006, s. 484.

${ }^{65}$ D.S. Sremac, War of words: Washington tackles the Yugoslav conflict, United States of America 1999, s. 202.

${ }^{66}$ Jej słowa dokładnie brzmiały następująco: społeczność międzynarodowa chciała „utopić Republikę Serbska w jednolitej Bośni i Hercegowinie”, a jej ,, obowią kiem jest ocalenie narodu od katastrofy; K. Časovski, op. cit., s. 20.

${ }^{67}$ M. Kuczyński, op. cit., s. 246.

${ }^{68}$ Wysoki Przedstawiciel zagroził, że jeśli bośniaccy Serbowie nie wyłonią kandydata na premiera w ciągu doby, zrobi to sam, a w przypadku dezaprobaty usunie oponentów z parlamentu. M. Kuczyński, op. cit. s. 246-247.

${ }^{69}$ R. Bideleux, I. Jeffries, op. cit., s. 369.

${ }^{70}$ Sz. Sochacki, op. cit., 185.

${ }^{71}$ M. Dodik był premierem RS w latach 1997-2001 i 2006-2010. Od 2010 roku jest prezydentem RS. W. Hebda, Republika Serbska Bośni i Hercegowiny - pytanie o przyszłość, w: Poznać Bałkany. 
W połowie września 1998 roku B. Plavšić przegrała wybory prezydenckie na rzecz Nikoli Poplašena, przedstawiciela Serbskiej Partii Radykalnej Republiki Serbskiej (Srpska Radikalna Stranka Republike Srpske, SRS RS), wspieranego także przez SDS, który podczas wojny bośniackiej dowodził oddziałami paramilitarnymi ${ }^{72}$. Na początku marca 1999 roku N. Poplašen został odwołany z urzędu przez Wysokiego Przedstawiciela $\mathrm{w}$ BiH z powodu nieskrywanej niechęci wobec współpracy z międzynarodowymi siłami ONZ na rzecz stabilizacji kraju ${ }^{73}$. Sama B. Plavšić wycofała się z polityki bośniackiej w pierwszej połowie 2000 roku, w związku z oskarżeniem jej o popełnienie zbrodni wojennych ${ }^{74}$. Na początku stycznia 2001 roku dobrowolnie poddała się ona jurysdykcji ICTY. B. Plavšić do października 2002 roku utrzymywała tezę o swojej niewinności ${ }^{75}$. Ostatecznie, w wyniku porozumienia stron, przyznała się do popełnienia zbrodni przeciwko ludzkości i została skazana na 11 lat więzienia. ICTY uznał jej winę $\mathrm{w}$ planowaniu, podjudzaniu, zarządzaniu, pomaganiu i wspieraniu prześladowań przeciwko bośniackim Muzułmanom i Chorwatom oraz innej nieserbskiej ludności w 37 regionach $\mathrm{BiH}$, w okresie od 1 lipca do 30 grudnia 1992 roku $^{76}$. Resztę zarzutów, w tym oskarżenie o zbrodnię ludobójstwa, oddalono. Za okoliczność łagodzącą Trybunał uznał wiek oskarżonej (w 2003 roku, w chwili ogłoszenia wyroku, B. Plavšić miała 72 lata), a także to, że ostatecznie przyznała się do winy, wyraziła skruchę i dobrowolnie stawiła się w Hadze. Bez wątpienia, do okoliczności łagodzących zaliczono także udział skazanej w implementacji porozumień z Dayton ${ }^{77}$.

Istotne jest to, że B. Plavšić jako jedna z nielicznych spośród oskarżonych przez ICTY wzięła odpowiedzialność za krwawy przebieg wojny w $\mathrm{BiH}^{78}$. Była też je-

Historia - Polityka - Kultura - Języki V, red. K. Taczyńska, A. Twardowska, Toruń 2013, s. 339, 342. Na początku 1998 roku przeniósł on stolicę RS z Pale do Banja Luki, gdzie od zakończenia wojny rezydowała B. Plavšić; R. Bideleux, I. Jeffries, op. cit., s. 369-370.

${ }^{72}$ Ibidem, s. 372.

${ }^{73}$ Sz. Sochacki, op. cit., s. 189.

${ }^{74}$ Akt oskarżenia przeciwko B. Plavšić dotyczył popełnienia zbrodni ludobójstwa, współudziału w ludobójstwie, eksterminacji, zabójstw, prześladowań, deportacji i innych nieludzkich aktów uznawanych za zbrodnie przeciwko ludzkości. Zgodnie z aktem oskarżenia, B. Plavšić uczestniczyła w tzw. joint criminal enterprises, czyli we wspólnym przedsięwzięciu kryminalnym, mającym na celu wyeliminowanie lub trwałe usunięcie bośniackich Muzułmanów, bośniackich Chorwatów i innych nieserbskich mieszkańców Bośni i Hercegowiny. Wcześniej uczestnictwo w tym procederze zarzucono także m.in. R. Karadžiciowi, M. Krajišnikowi, R. Mladiciowi. Plavsic - Initial Indictmen - http://www.icty.org/x/cases/plavsic/ind/en/ pla-ii000407e.pdf, [dostęp: 21.12.2016]; K. Wierczyńska, Pojęcie ludobójstwa w kontekście orzecznictwa międzynarodowych trybunałów karnych ad hoc, Warszawa 2010, s. 99; A. Szpak, Zbrodnie w Srebrenicy i Sarajewie przed Międzynarodowym Trybunatem Karnym ds. Zbrodni w byłej Jugostawii. Casus Ratko Mladicia, „Ruch Prawniczy, Ekonomiczny i Socjologiczny”, 2012, R. 74, nr 4, s. 80.

${ }^{75}$ K. Bachmnann, A. Fatić, The UN International Criminal Tribunals. Transition without justice?, New York 2015, s. 126.

${ }^{76}$ A. Aganović, Z. Delić, Devedesete. Rat i nakon rata u Bosni i Hercegovini, w: Zabilježene - žene i javni život Bosne i Hercegovine u 20. vijeku, ed. E. Bošnjak, S. Gavrićs, Sarajevo 2014, s. 215.

${ }^{77}$ K. Wierczyńska, op. cit., s. 99.

${ }^{78}$ A. Bachmann, A. Fatić, op. cit., s. 127. 
dyną kobietą, która stanęła przed Trybunałem w charakterze oskarżonej ${ }^{79}$. Jej przyznanie do winy odbiło się szerokim echem w prasie, wyrażano nadzieje, że w ślady B. Plavšić pójdą inne osoby, poddane procedurze ICTY ${ }^{80}$. Początkowy entuzjazm gasiły jednak kontrowersje wokół powodów przyznania się byłej prezydent RS do winy. Pisano między innymi, że oskarżona nie wyraziła prawdziwej skruchy za swojej działania i ciągle usprawiedliwiała rolę Serbów bośniackich w konflikcie z pierwszej połowy lat $90 \mathrm{XX}$ wieku ${ }^{81}$. Miały na to wskazywać oświadczenia B. Plavšić, że przyznała się do winy z myślą o łagodniejszym wyroku. Jak tłumaczyła, aby uratować siebie przed maksymalnym wymiarem kary, musiała skłamać i odegrać akt skruchy ${ }^{82}$.

B. Plavšić odbyła karę wiezienia w Szwecji, w więzieniu dla kobiet w Heinsbergu. Dwukrotnie, w 2007 i 2008 roku, bezskutecznie wnioskowała o zwolnienie przedterminowe. Uważała, że jako profesor nie powinna przebywać między prostytutkami, mordercami, narkomanami, złodziejami ${ }^{83}$. Ostatecznie o jej przedterminowym zwolnieniu z więzienia w 2009 roku przeważyło dobre sprawowanie ${ }^{84}$. Co ciekawe, zwracano uwagę na jej niewielką wartość jako ewentualnego świadka w procesach osób oskarżonych przez ICTY, w tym także S. Miloševicia ${ }^{85}$. W więzieniu B. Plavšić zdążyła spisać swoje wspomnienia, wydając je w dwóch tomach pod tytułem Svedočim. Autorka bynajmniej nie rezygnowała z retoryki nacjonalistycznej i starała się przekonać czytelników o swej udawanej skrusze okazanej przed Trybunałem ${ }^{86}$.

Trudno o jednoznaczną charakterystykę i ocenę politycznej działalności B. Plavšić. Wyczerpującej odpowiedzi na to pytanie nie udzielają ani opracowania naukowe, ani artykuły prasowe. $Z$ jednej strony akcentuje się jej współodpowiedzialność w zbrodniach popełnionych podczas wojny bośniackiej. Z drugiej trudno jednoznacznie wskazać czy oprócz głoszenia haseł skrajnie nacjonalistycznych, podgrzewających nienawiść na tle etnicznym, odegrała ona poważniejszą rolę decyzyjną w latach 1992-1995. Okres jej prezydentury oraz epizod związany z procesem ICTY i więzieniem niosą wiele zasadniczych pytań. Należy podkreślić, że B. Plavšić, w odróżnieniu od R. Mladicia czy R. Karadžicia, nie jest umieszczana przez serbskich nacjonalistów w panteonie współczesnych bohaterów narodowych i zarazem męczenników za serbską sprawę narodową. Choć dała się zapamiętać jako osoba o poglądach skrajnie nacjonalistycznych, jej działalność budzi sprzeczne odczucia wśród Serbów.

\footnotetext{
${ }^{79}$ Por. A. Aganović, Z. Delić, op. cit., 179-180.

${ }^{80}$ O. Simic, Bringing 'Justice' Home? Bosnians, War Criminals and the Interaction between the Cosmopolitan and the Local, "German Law Jounal", 2011, vol. 12, no. 07, s. 1398.

${ }^{81}$ J. Subotić, op. cit., s. 46.

82 O. Simic, op. cit., s. 1400.

${ }^{83}$ Pismo Biljane Plavšić vedskom Ministarstvu - http://arhiva.dalje.com/hr-svijet/pismo-biljane-plavsi-svedskom-ministarstvu/16524, [dostęp: 24.09.2016].

${ }^{84}$ P.R. Bartrop, op. cit., s. 255

${ }^{85}$ Plavšićeva stila u Beograd - http://www.rts.rs/page/stories/sr/story/135/hronika/254661/plavsiceva-stigla-u-beograd.html, [dostęp: 24.09.2016].

${ }^{86}$ O. Simic, op. cit., s. 1389,1400 .
} 


\section{BIBLIOGRAFIA}

Aganović Arijana, Delić Zlatan, Devedesete. Rat i nakon rata u Bosni i Hercegovini, w: Zabilježene - žene i javni život Bosne i Hercegovine u 20. vijeku, ed. E. Bošnjak, S. Gavrićs, Sarajevo 2014.

Bachmnann Klaus, Fatić Aleksandar, The UN International Criminal Tribunals. Transition without justice?, New York 2015.

Bartrop Paul R., A Biographical Encyclopedia of Contemporary Genocide: Portraits of Evil and Good, United States of America 2012.

Bideleux Robert, Jeffries Ian, The Balkans. A post-Communist history, New York 2007.

Bildt Carl, Peace Journey. The Struggle for Peace in Bosnia, Great Britain 1998.

Biljana Plavšić, w: Republika Srpka. Prvi internet portal Republike Srpske - http://www.republikasrpska. net/predsjednici/biljana-plavsic/, [dostęp: 06.09.2016].

Biljana Plavšić: Želim da me svi zaborave... - http://www.radiosarajevo.ba/vijesti/bosna-i-hercegovina/ biljana-plavsic-zelim-da-me-svi-zaborave/195918, [dostęp: 06.09.2016].

Bugarel Ksavije, Bosna. Anatomija rata, przeł. J. Stakić, Beograd 2004.

Bujwid-Kurek Ewa, Rola Alii Izetbegovicia w kształtowaniu muzułmańskiej wspólnoty narodowej Bośni $i$ Hercegowiny, „Slavia Medirionalis” 11 (2011).

Cook Bernard, Plavsic, Biljana (1930 - ), w: Women and War. A Historical Encyclopedia from Antiquity to the Present, vol. II, ed. B.A. Cook, United States of America 2006.

Čavoški Kosta, Lutka u tuđim rukama. Od uzurpacije do izdaje, Beograd 1998.

Donia Robert, Iz skupštine Republike Srpske 1991-1996. Izvodi iz izlaganja poslanika skupštine Republike Srpske kao dokazni materijal na Međunarodnom Krivičnom Tribunalu u Hagu, Sarajevo - Tuzla 2012.

Evangelista Matthew, Gender, Nationalism and War. Conflict on the Movie Screen, New York 2011.

Habarta Maciej, Kobiety zbrodniarki. Na przekór batkańskiemu patriarchalizmowi i stereotypom ptci, „Znaczenia. Kultura-komunikacja-społeczeństwo”, 10/2014. Artykuł dostępny na stronie - http:// www.e-znaczenia.pl/?p=1095, [dostęp: 24.09.2016].

Hebda Wiktor, Republika Serbska Bośni i Hercegowiny - pytanie o przyszłość, w: Poznać Batkany. Historia - Polityka - Kultura - Języki V, red. K. Taczyńska, A. Twardowska, Toruń 2013.

Hunt Swanee, World Apart. Bosnian Lessons for Global Security, United States of America 2011.

Gallagher Tom, The Balkans after the Cold War. From tyranny to tragedy, London 2003.

de Guzman M.M., Proportionate Sentencing at the ICC, w: The Law and Practise of the International Criminal Court, red. C. Stahn, United Kingdom 2015.

Kuczyński Maciej, Krwawa Europa. Konflikty zbrojne i punkty zapalne w latach 1990-2000. Tto historyczne i stan obecny, Warszawa 2001.

Krupić Almira, Žene ratni zločinci s posebnim osvrtom na žene izvršioce ratnih zločina u Bosni i Hercegovini 1992-1995, Sarajevo 2010.

Krysienel Krzysztof, Ewolucja systemu politycznego Bośni i Hercegowiny w latach 1990-1995, w: Bałkany Zachodnie między przeszłościa a przyszłościa, red. P. Chmielewski, S.L. Szczesio, Łódź 2013.

Krysienel Krzysztof, $W$ cieniu Dayton. Bośnia i Hercegowina między etnokracją i demokracja konsocjonalna, Warszawa 2012.

LeBor Adam, Milosevic. A Biography, Great Britain 2002.

Lilly Carol S., Irvine Jill A., Leading the Nation: Extreme Right Women Leaders Among the Serbs, w: Women of the Right. Comparisions and Interplay Across Borders, eds. K.M. Blee, S. McGee Deutsch, United States of America 2012.

Lovrenović Ivan, Bosnia. A Cultural History, przeł. S. Wild Bičanić, New York 2001.

Marković M., Biljana Plavšić: Nemam nijedne ružne reči o Mladiću - http://www.novosti.rs/vesti/naslovna/dosije/aktuelno.292.html:332500-Biljana-Plavsic-Nemam-nijedne-ruzne-reci-o-Mladicu, [dostęp 24.09.2016]. 
Oliver Ian, War \& Peace in the Balkans. The Diplomacy of Conflict in the Former Yugoslavia, New York 2005.

Parish Matthew, A Free City in the Balkans. Reconstructing a Divided Society in Bosnia, New York 2010.

Pismo Biljane Plavšić vedskom Ministarstvu - http://arhiva.dalje.com/hr-svijet/pismo-biljane-plavsi-svedskom-ministarstvu/16524 - [dostęp: 24.09.2016].

Plavsic - Initial Indictmen - http://www.icty.org/x/cases/plavsic/ind/en/pla-ii000407e.pdf, [dostęp: 21.12.2016].

Plavšićeva bez akademiskih prava u Sarajevu - http://www.novosti.rs/vesti/naslovna/drustvo/aktuelno.290.html:255472-Plavsiceva-bez-akademskih-prava-u-Sarajevu, [dostęp: 06.09.2016].

Plavšićeva stila u Beograd - http://www.rts.rs/page/stories/sr/story/135/hronika/254661/plavsiceva-stigla-u-beograd.html, [dostęp: 24.09.2016].

Ramet Sabina P., The Three Yugoslavias. State-Building and Legimation, 1918-2015, United States of America 2006.

Rekść Magdalena, Polityka historyczna jako instrument manipulacji przestrzeniami zbiorowymi na przykladzie Bałkanów, w: Bałkany w XXi XXI wieku. Historia - Polityka-Kultura. Materiały z konferencji „,Poznać Bałkany”, Toruń, 29 maja 2009 roku, red. H. Stys, Sz. Sochacki, Toruń 2009.

Rogel Carole, The breakup of Yugoslavia and its aftermath, United States of America 2004.

Simic Olivera, Bringing 'Justice' Home? Bosnians, War Criminals and the Interaction between the Cosmopolitan and the Local, "German Law Jounal", 2011, vol. 12, no. 07.

Sochacki Szymon, Bośnia i Hercegowina 1995-2012. Studium politologiczne, Torun 2015.

Sremac Danielle., War of words: Washington tackles the Yugoslav conflict, United States of America 1999.

Stephen Chris, Judgement Day. The Trial of Slobodan Milošević, London 2004.

Subotić Jelena, The Cruelty of False Remorse: Biljana Plavšić at The Hague, "Southeastern Europe", 2012, nr 36.

Szczesio Sławomir, Droga ku wojnie - sytuacja w Bośni i Hercegowinie w latach 1990-1992, w: Bałkany w XX i XXI wieku. Historia - Polityka - Kultura. Materiały z konferencji „Poznać Bałkany”, Toruń, 29 maja 2009 roku, red. H. Stys, Sz. Sochacki, Toruń 2009.

Szpak Agnieszka, Zbrodnie w Srebrenicy i Sarajewie przed Międzynarodowym Trybunatem Karnym ds. Zbrodni w bytej Jugostawii. Casus Ratko Mladicia, „Ruch Prawniczy, Ekonomiczny i Socjologiczny", 2012, R. 74, nr 4.

Vojislav Šešelj o Biljani Plavšič - https://www.youtube.com/watch?v=9rcf3sM2Sso, [dostęp: 24.09. 2016].

Wierczyńska Karolina, Pojęcie ludobójstwa w kontekście orzecznictwa międzynarodowych trybunałów karnych ad hoc, Warszawa 2010.

Wybranowski Dariusz, Armia Republiki Serbskiej w Bośni (1992-1995) - geneza, struktura i pierwsze lata istnienia, [w:] Bałkany Zachodnie między przeszłością a przyszłością, red. P. Chmielewski, S.L. Szczesio, Łódź 2013.

Wybranowski Dariusz, Między niepodległościa a dezintegracja. Bośnia i Hercegowina w XX i XXI wieku, Szczecin 2011.

Wybranowski Dariusz, Proces redukcji i kres istnienia Armii Republiki Serbskiej w Bośni (1995-2006), „Bezpieczeństwo. Teoria i Praktyka” 2012, t. 8, nr 3. 